\title{
Boosting Creativity with Transformational Leadership in Fuzzy Front-end Innovation Processes
}

\author{
Mirva Hyypiä and Satu Parjanen \\ Lappeenranta University of Technology, Finland
}

\author{
mirva.hyypia@lut.fi; satu.parjanen@lut.fi
}

\begin{abstract}
One of the contemporary demands in organizations is the need to create new knowledge and innovations. The purpose of this study is to clarify how creativity for the fuzzy front-end innovation processes can be supported by transformational leadership. In addition, the study aims at recognizing (a) challenges that organizations confront at the beginning of innovation processes and (b) what characters of transformational leadership are emphasized as well as how leaders should react during these challenging processes. The qualitative data used in this study is a partial case study from a wider action research-based development project, which aims at revealing the hidden innovation potential at different levels of an organization. Creativity and innovation are essential parts of development processes. This study contributes to the current literature on search strategies in relation to transformational leadership (TL) by extending the understanding of how to support employees' creativity and involve employees in discovering new innovation opportunities. In addition, this study suggests that TL's characteristics can be shared positively in practice as well as be performed simultaneously in the same organization development process by different leaders.
\end{abstract}

Keywords: Creativity, Transformational Leadership, Innovation Process, Knowledge sharing

\section{Introduction}

An organization's success and survival depend on its capability to create new knowledge and innovations. Knowledge is an organization's most valuable resource because it embodies intangible assets, routines, and creative processes that are difficult to imitate. Different types of knowledge require distinct management methods and knowledge integration mechanisms (Birasnav, Rangnekar, \& Dalpati, 2011; Miles, Miles, \& Snow, 2000; Nonaka \& Takeuchi, 1995; Pöyhönen, 2006). Many current approaches to innovation hold the assumption that organizations are seldom capable of innovating independently and that an organization's internal capabilities are insufficient to cope with the challenges of the changing environment. The search for new product ideas,

Material published as part of this publication, either on-line or in print, is copyrighted by the Informing Science Institute. Permission to make digital or paper copy of part or all of these works for personal or classroom use is granted without fee provided that the copies are not made or distributed for profit or commercial advantage AND that copies 1) bear this notice in full and 2) give the full citation on the first page. It is permissible to abstract these works so long as credit is given. To copy in all other cases or to republish or to post on a server or to redistribute to lists requires specific permission and payment of a fee. Contact Publisher@,InformingScience.org to request redistribution permission. new forms of organization, and solutions to existing problems goes beyond the organization's boundaries in exploring available capacities in other organizations.

What is common to the models of innovation is that they highlight the interactive character of the innovation process, suggesting that organizations rely heavily on their interaction with users, sup- 
pliers, and a range of other organizations inside the innovation system (Chesbrough, 2003; Lettl, Herstatt, \& Gemuenden, 2006; von Hippel, 1988). For example, von Hippel (1988) suggested using lead users and other stakeholders as external sources of innovation. These models further redefine the inbound-innovation-process by extending von Hippel's (1988) sources of innovation to include universities, suppliers and online communities (Christensen, Olesen, \& Kjaer, 2005) or basically to any external expert (Bogers \& West, 2010).

The generation and implementation of significant new ideas, products, and processes may also originate from a single employee or the joint efforts of two or more employees who are not assigned to this task. Thus, these kinds of innovations indicate that innovations can emerge from shop floor workers and professionals or middle managers across the boundaries of existing departments and professions. The basic idea of employee-driven innovation rests on the assumption that employees have hidden abilities for innovation (Forssén, 2001), and that this potential can be made visible, recognizable, and exploitable to the benefit of both the organisation and its employees (Kesting \& Ulhøi, 2010).

The work environment, atmosphere, and trust are very important in order to get more effort from employees. Intrinsic motivation is arguably the most valuable aspect enhancing employees' creativity. Intrinsically motivated employees do their job well regardless of whether they are supervised or not; they have strong intrinsic motivators and have a passion for doing something for innovating (Felberg \& DeMarco, 1992; Knight, 1987; Thomas \& Velthouse, 1990). When people feel that the assignment itself is exciting and rewarding, they will share knowledge (Miles, Miles $\&$ Snow, 2005). Employees' feelings that the organization values their contribution and is interested in their wellbeing are positively related to their performance and organizational commitment (Joo, Yoon, \& Jeung, 2012; McDonald \& Makin, 2000; Paalanen \& Hyypiä, 2008; Tsui \& $\mathrm{Wu}, 2005)$. Since innovation at the organizational level is a combination of collaboration, creative results, and achievements, investigating the effect of leadership and its influence on employees' contribution and creativity can be significant (Amabile, 1998; Gumusluoglu \& Ilsev, 2009).

The concept of transformational leadership (TL) has received much attention from researchers, particularly from the perspective of the employees and the organization's performance. Most of these studies are based on quantitative data or literature reviews. However, the effects of TL on employees' creativity and innovation in practice during organization development processes have received little attention (Birasnav et al., 2011; Gumusluoglu \& Ilsev, 2009; Liu \& DeFrank, 2011). This research paper aims to reveal how creativity in the fuzzy front-end innovation processes is supported by characteristics of transformational leadership. The study is based on part of a wider action research process conducted in one organization and its area units. This is examined by observing two leaders and their interaction with sales managers. The data on how salespeople observed customers and shared knowledge among colleagues is based on the interviews of salespeople themselves, i.e., their evaluation of their own behavior. Observational data is organized in the form of diaries and notes. Literary material co-produced by the participants during organized sessions is also used as data.

\section{Creativity in Fuzzy Front-end Innovation Processes}

Creativity is one of many critical factors behind innovation and is necessary throughout the whole process (Mumford, Scott, Gaddis, \& Strange, 2002). Innovation through creativity is an important factor in the success and competitive advantage of organizations (Woodman, Sawyer, \& Griffin, 1993). Changes within the business environment require new and creative ways of organizing and managing organizations. Creativity plays an important role in the long-term survival and development of organizations because it is the basis of successful innovation and provides organizations with the means of coping with change (Amabile, 1997; Woodman et al., 1993). An organization that supports creativity and influences the adoption of innovative practices, products, and 
services improves an organization's ability to remain competitive. That is why creativity has been seen as an essential goal for many organizations and as potentially having influence on organizational performance (Drazin, Glynn, \& Kazanjian, 1999; Mumford et al., 2002; Parjanen, 2012c).

The focus of this study is to examine transformational leadership behavior that enhances creativity especially at the beginning of the innovation process. This phase is often called the fuzzy front-end (Khurana \& Rosenthal, 1998; Koen et al., 2002). Typical tasks of the fuzzy front-end are idea generation and concept development. However, relatively little is known about the key activities that constitute the fuzzy front-end, how these activities can be managed, which actors that participate, as well as how much time is needed to complete this phase. Many organizations also seem to have great difficulties in managing the fuzzy front-end in practice. The fuzzy front end is a crossroads of complex information processing, tacit knowledge, conflicting organizational pressures, and considerable uncertainty. In addition, this phase is also often ill-defined. (Alam, 2006; Khurana \& Rosenthal, 1998.) The phases of the innovation process are introduced in Figure 1. Yet, in practice, innovation processes often differ from theoretical process models. Some phases may be left out; others may be revisited in a cyclical fashion. (Herstatt \& Verworn, 2001; Parjanen, 2012a)

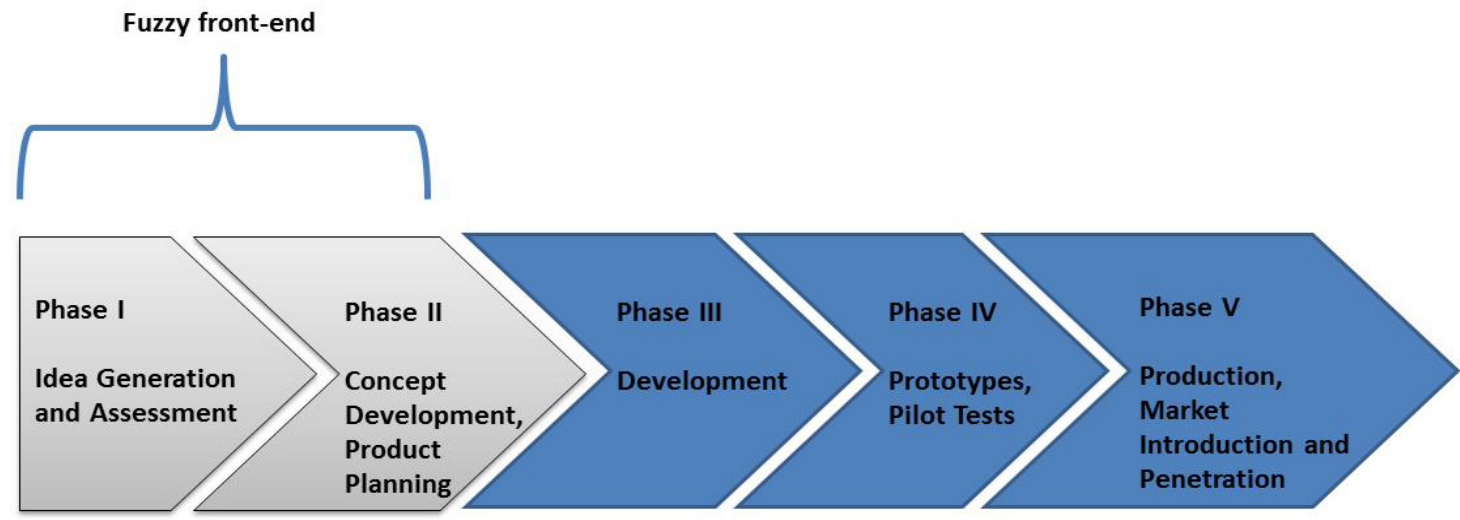

Figure 1. The Fuzzy front-end phase of the innovation process (Source: Herstatt \& Verworn, 2001)

Characteristic of this phase, besides the need to systematize activities to enhance efficiency, is the need of sufficient room for creativity (Herstatt \& Verworn, 2001). Creativity refers to pure ideas; innovation is the successful translation of ideas into tangible products or intangible services. Not all creative ideas are innovative. As such, the outcome of the innovation - be it incremental or radical - is not really the focus of this study. Therefore, in this study emphasis is on the development process, exploring the procedures that enhance creativity and innovations among individuals in the organization.

Research on creativity at the organizational level can in general be divided into two categories: the characteristics of the members of the organization and the characteristics of the organization that facilitate and nurture employee creativity. Research suggests that employee creativity makes a substantial contribution to organizational innovation, effectiveness, and survival (Amabile, 1996; Axtell et al., 2000; Nayak, 2008; Nijhof, Krabbendam, \& Looise, 2002). By generating creative ideas, employees provide new solutions and possibilities that benefit the organization. To make distinctions between employee creativity and innovativeness, it can be argued that every innovation needs creativity, but creativity does not necessarily lead to innovation. An employee's engagement in innovative work behavior requires the employee to be both able and willing to be creative. Amabile (1997) writes that three areas of creativity, i.e., expertise, creative-thinking 
skills, and motivation, when mixed together, identify the level of creativity within an individual. Employee innovativeness can thus be argued to cover a broader range of behaviors than creativity (de Jong \& Kemp, 2003; Parzefall, Seeck, \& Leppänen, 2008).

Nowadays creativity is increasingly understood as a social phenomenon, especially in an organizational context. For example, Madjar (2005) explores the relevance of sets of other individuals, both inside and outside the boundaries of the organization, who have the potential to influence creative performance. Others may stimulate creativity by presenting new information and knowledge to the employee, which in turn trigger novel ideas and alternative solutions. Others can give examples, raise different issues, make certain perceptions more visible, and provide alternative situations and comparison points. In addition, different groups can influence creativity by simply reformulating the existing knowledge and information, and providing new perspectives on it. The employees' collaboration with people from different departments and different organizations can provide information that is beneficial to the generation of new ideas. (Parjanen, 2012c)

Creative achievements like innovations are more and more often created in collaboration with different actors. Creativity is often associated with diversity of knowledge, skills, experiences, and perspectives. Collaboration between diverse actors thus triggers creativity. Actually, there is increasing consensus that diversity provides the potential for innovation (e.g., Carlile, 2002, 2004; Johansson, 2004; Leonard, 1995; Parjanen, 2012a). Innovations involve the challenge of enabling renewal based on diversity and facilitating the integration of knowledge in a creative way. This is the reason why too proximate relations may have negative impacts on innovation due to the problem of lock-in (Boschma, 2005).

Organizational factors such as structure and culture may play a more important role in predicting the realization of innovations than in influencing the employee tendency to produce creative and innovative ideas (Axtell et al., 2000). Continuous communication can increase creativity and innovativeness, because it accumulates knowledge inside the organization, and it becomes possible to develop these shared ideas: to modify them to become more diverse. For example, among the different area units of an organization, knowledge sharing and tacit knowledge might be an effective way to create positive change, even on an organizational level (Bass \& Avolio, 2000). Flexible and flat organizational structures improve innovativeness and make idea generation and communication more open. In addition, flexible organizational structures and a supportive organizational culture create better communication throughout the company and can generate more innovative, creative, and committed employees at all organizational levels (Adamides \& Karacapilidis, 2004; Jacobsen, Hofman-Bang, \& Nordby, 2005; Oikarinen, 2008; Schein, 1999; Wan, Ong, \& Lee, 2005).

In many studies managerial behaviors have been connected to employees' creative performance. Leaders may support employees' creativity by allocating resources. One of the most valuable resources that leaders may allocate in order to foster creativity is time (Mumford \& Gustafson, 1988). Access to funds, materials, facilities, and information also supports creativity (Amabile, Conti, Coon, Lazenby, \& Herron, 1996). Leaders can also influence creativity in the way they design work groups. According to research (Amabile et al., 1996; Milliken \& Martins, 1996), work groups conducive to creativity have diversely skilled members, an openness to new ideas, inter-personal trust, commitment to the work, and communication where members constructively challenge each other's ideas. In particular, diversity in group composition provides potential for innovation (e.g., Johansson, 2004; Paulus, 2000). Innovations involve the challenge of enabling renewal based on diversity and facilitating the integration of knowledge in a creative way. Job characteristics that relate to creativity, including complexity, autonomy, variety, and feedback, also support creativity at the work place. Also supportive leadership is positively related to employee creativity (Oldham \& Cummings, 1996). Leaders may provide encouragement to creativ- 
ity by valuing individuals' contributions and showing confidence in the work group (Amabile et al., 1996).

\section{Boosting Creativity with Leadership Behavior}

Innovation processes are organizationally counterintuitive and cannot be managed hierarchically because innovation is based on the idea that knowledge is exchanged of one's free will. However, this does not mean that creativity and innovation processes do not need management responsibilities or leadership at all (Drucker, 2007; Viitala, 2004). Innovation emerges when the knowledge from previously separated domains is exchanged and combined in new ways (Miles et al., 2000; Nahapiet \& Ghostal, 1998).

Founded on the early ideas of Peter F. Drucker (1964), planning, organizing, controlling, motivating, and coordinating are the basic functions of management work. This categorization is still the basis for many role definitions, especially in leadership and managerial tasks (Figure 2). There are multiple sources in literature on how to divide different tasks under different roles (Kotter, 1990; Miles \& Snow, 1986; Mintzberg, 1989; Ulrich \& Beatty, 2002). A very common division is made between manager and leader. Often, this differentiation means that roles that concern the tasks and systems at hand are for managers whereas leaders are responsible for people and vision sharing. On the other hand, today we understand that you have to be both a manager and a leader in order to be effective (Drucker, 2007; Sydänmaanlakka, 2003).
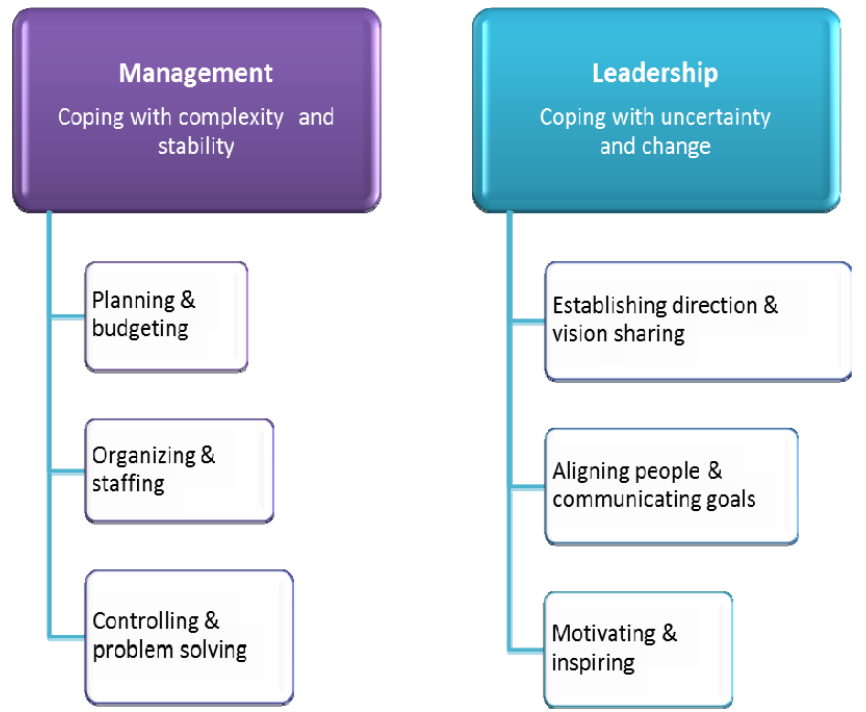

Figure 2. Distinction of Management vs. Leadership

(Source: Huusko, 2006; Kotter, 1990; Lunenburg, 2011)

With the aim of increasing creativity and meeting the expectations of communication, companies should have a suitable and purposeful leadership style. The concept of TL was created by Burns (1978). His ideas were based on researching political leaders. The central idea behind Burns' concept is that leadership is a process, not a set of discrete acts. Leadership is described as a system where leaders constantly try to develop motivational responses to followers, as well as to adapt differently to their responsiveness or resistance (Kotter, 1996; Viitala, 2005; Yukl, 1998). As a comparison, authors often reflect differences between transactional and transformational leadership. The transactional leadership style is focused more on rewards and punishment than on transforming mindsets or involving the employees (Bass \& Avolio, 2000; Yukl, 1998).

Bass (1985) has developed the ideas of Burns' TL concept. The basic idea of Bass is that TL can be clarified in terms of the impact leaders have on followers. These effects and reactions can be 
seen, for example, in the followers' feelings of trust, loyalty, respect for leaders, and willingness to go beyond their job description. According to Viitala (2004) the TL style is a long process and its results can be seen in the long run. In order to transform and motivate employees, Bass suggests that leaders should pursue the following guidelines:

1. Make employees more aware of the importance of the task outcome;

2. Encourage employees to exceed their own self-interest concerning the organization or team; and

3. Trigger employees' higher-order needs. (Birasnav et al., 2011; Yukl, 1998)

The four dimensions of TL are idealized influence (or charisma), inspirational motivation, intellectual stimulation, and individual consideration, as presented in the Table below.

Table 1. The four dimensions (the 4 Is) of TL

\begin{tabular}{|c|l|}
\hline TL and the 4 Is & \multicolumn{1}{c|}{ Characterization } \\
\hline $\begin{array}{c}\text { Idealized Influ- } \\
\text { ence }\end{array}$ & $\begin{array}{l}\text { Refers to how leaders' admirable behavior can cause followers } \\
\text { to identify with the leader; appealing to followers on an emo- } \\
\text { tional level. This is about leaders' ability to provide a role model } \\
\text { for their followers by having a clear set of values and demon- } \\
\text { strating them in every action. }\end{array}$ \\
\hline $\begin{array}{c}\text { Inspirational } \\
\text { Motivation }\end{array}$ & $\begin{array}{l}\text { Leaders articulate a vision that is interesting and inspiring to } \\
\text { followers, challenge them with high standards, communicate } \\
\text { optimism about future goals, and provide meaning for the task at } \\
\text { hand. Followers need to have a strong sense of purpose if they } \\
\text { are to be motivated to move forward individually as well as } \\
\text { within groups. }\end{array}$ \\
\hline $\begin{array}{c}\text { Intellectual } \\
\text { Stimulation }\end{array}$ & $\begin{array}{l}\text { Leaders are able to increase the awareness of problems and per- } \\
\text { suade employees to deal with them from different perspectives. } \\
\text { Moreover, leaders challenge assumptions, take risks, and seek } \\
\text { ideas from employees to stimulate and encourage creativity } \\
\text { among them. }\end{array}$ \\
\hline $\begin{array}{c}\text { Individual } \\
\text { Consideration }\end{array}$ & $\begin{array}{l}\text { This is about how the leader attends to each follower's needs, } \\
\text { acts as a mentor or coach, and listens to their concerns and de- } \\
\text { mands. This also covers the need to respect and celebrate the } \\
\text { individual input that each employee is able to contribute to the } \\
\text { team. }\end{array}$ \\
\hline
\end{tabular}

TL can be clarified as being processes aiming to build commitment toward organizations' goals and empowering employees to achieve these goals. In addition, some theories suggest that with TL it is possible to explore the effects leaders have on organizational culture while accomplishing organizational objectives.

According to Bass and Riggio (2006), the variables of the different dimensions (the 4 Is) are not explanatory per se, but the substantial value is in the process as a whole. This means that the different dimensions are all needed in order to influence people and partners, as well as to accomplish positive outcomes with collaboration (Kotter \& Cohen 2002; Senge 2003). The four dimensions can also be looked at as different roles that are beneficial in changed situations. TL is able to boost creativity and innovation, since the idea is to stimulate and be involved with the partici- 
pants in developing processes rather than being the source of groups' innovation. The responsibility for the leadership in this sense is not to tell participants what to do but to encourage and provide a climate that supports their creativity and innovation efforts. TL has positive outcomes related to trust, group performance with groups that are not in contact face to face, and cohesiveness among work groups in general. These are gained by maintaining the integrity and dedication of followers and participants. In addition, the fairness and faith that associates perceive from TL behavior has a significant influence on positive outcomes (Bass \& Riggio, 2006; Birasnav et al., 2011;Yukl, 1998).

\section{Methodology}

The aim of the study is to clarify how creativity for the fuzzy front-end innovation processes can be supported by transformational leadership. Additionally, the study aims at recognizing a) challenges that organizations confront at the beginning of creativity and innovation processes and $b$ ) what characters of transformational leadership are emphasized as well as how leaders should react during these challenging processes. However, in this study managerial or leadership roles are not reflected with the common and somewhat traditional distinguishing (Figure 2). In this study the employees are white-collar workers i.e. Sales managers and leaders (Vice President and President) are also owners of the company. The leaders represent a new generation at the ownership level and as consequence some of the managers have been working longer for the company than the leaders themselves.

\section{Background of the Case Study}

The case company is a medium sized organization that operates internationally in the wood processing industry. In addition to traditional timber production and timber components, the company makes laminated timber, planed timber, and weatherproofed columns, as well as other impregnated products. The headquarters and seven area units are located in Finland and the company has, on average, 740 employees.

The data used in this study is a partial case from a wider action research-based development project, which aims at revealing the hidden innovation potential at different levels of an organization. The action research-based project is called the Innovation Catcher. The Innovation Catcher is one of the tools based on innovation theories and applied to different needs in different organizations. It has been developed in co-operation between a university and local industry in the Lahti region of Finland and has been tested in research and development projects from 2007 to 2008. In addition to the basic shop-floor level of industries, the Innovation Catcher has been tested in public sector organizations whose distinctive features present new challenges. Furthermore, the Innovation Catcher was also tested in the expert organization that is the case company in this particular study (Kallio \& Konsti-Laakso, 2011).

In this particular case study, the focus of the Innovation Catcher was to improve the exploration and use of customer knowledge, primarily between managers and leaders, and therefore was initially chosen to be analyzed in this paper. Managers continuously received the required figures relating to customers and current needs but the weak signals of possible near future needs could not be deduced from these figures. When the salespeople returned after a visit to a customer, they might inform their manager about important observations, but this was not done in any systematic way and potentially relevant information got lost. (See more about the action research process and Innovation Catcher: Kallio \& Bergenholtz, 2011; Kallio \& Konsti-Laakso, 2011). 
Table 2. Core phases of the Innovation Catcher process

(Source: Kallio \& Konsti-Laakso, 2011)

\begin{tabular}{|c|c|c|c|}
\hline Phase & Content & Working method & Output of the phase \\
\hline \multicolumn{4}{|c|}{ 1. Diagnosis: locating the development need } \\
\hline $\begin{array}{l}\text { 1.1. Meeting the } \\
\text { leaders }\end{array}$ & $\begin{array}{l}\text { Need and resources } \\
\text { for the process }\end{array}$ & Meeting & $\begin{array}{l}\text { What do leaders think } \\
\text { about the current state } \\
\text { of things? }\end{array}$ \\
\hline 1.2 Interviews & $\begin{array}{l}\text { Presupposition of } \\
\text { where to target the } \\
\text { actions } \\
\text { Awareness of the } \\
\text { state of the innova- } \\
\text { tion capability of the } \\
\text { organization }\end{array}$ & $\begin{array}{l}\text { Semi-structured } \\
\text { interviews }\end{array}$ & $\begin{array}{l}\text { What do managers } \\
\text { think is the current } \\
\text { state of things? }\end{array}$ \\
\hline 1.3 Session 1 & $\begin{array}{l}\text { The actual develop- } \\
\text { ment focus and indi- } \\
\text { vidual motivation }\end{array}$ & $\begin{array}{l}\text { Creative working } \\
\text { methods }\end{array}$ & $\begin{array}{l}\text { Shared view of the } \\
\text { development focus; } \\
\text { Motivation to continue }\end{array}$ \\
\hline \multicolumn{4}{|c|}{ 2. Creating content } \\
\hline 2.1 Session 2 & Idea generation & $\begin{array}{l}\text { Creative working } \\
\text { methods }\end{array}$ & $\begin{array}{l}\text { Ideas for practices, } \\
\text { roles, models that en- } \\
\text { hance innovativeness }\end{array}$ \\
\hline $\begin{array}{l}2.2 \text { Work assign- } \\
\text { ments }\end{array}$ & Testing the ideas & $\begin{array}{l}\text { Observation, notes, } \\
\text { researcher mentor- } \\
\text { ing }\end{array}$ & $\begin{array}{l}\text { What is possible to } \\
\text { implement in everyday } \\
\text { work? }\end{array}$ \\
\hline 2.3 Session 3 & $\begin{array}{l}\text { The questions that } \\
\text { need to be solved }\end{array}$ & $\begin{array}{l}\text { Creative working } \\
\text { methods }\end{array}$ & $\begin{array}{l}\text { A solution that will be } \\
\text { implemented }\end{array}$ \\
\hline \multicolumn{4}{|c|}{ 3. Agreement } \\
\hline 3.1 Agreement & $\begin{array}{l}\text { Resources and com- } \\
\text { mitment }\end{array}$ & $\begin{array}{l}\text { Meeting table with } \\
\text { roles }\end{array}$ & $\begin{array}{l}\text { To ensure different } \\
\text { viewpoints }\end{array}$ \\
\hline 3.2 Reflection & Evaluation & $\begin{array}{l}\text { Reflective dis- } \\
\text { course, question- } \\
\text { naire }\end{array}$ & $\begin{array}{l}\text { To evaluate the process } \\
\text { and innovation capabil- } \\
\text { ity }\end{array}$ \\
\hline
\end{tabular}

\section{Data Gathering}

The qualitative research method is a semi-structured interview, as it allows interviewees to explain their own perceptions and matters concerning themselves more freely. This is especially relevant when the object of the research is not fully clarified, when the area is unknown or, especially, when answers are wanted to be set in a wider context (Hirsijärvi \& Hurme, 2000). The interviews were conducted by two researchers. The themes of the interviews were the channels through which salespeople's ideas were moved on in the organization, their ways of acquiring knowledge related to customers and colleagues, their motivation for their work, their perception of the leadership behavior, and the overall atmosphere in the company (as a whole) and its area units.

As the interview process evolved and the understanding and the knowledge of the researchers accumulated, some more specific questions were added to the semi-structured interviews. The software ATLAS.ti was used to help analyze the data. The reliability of coding is important in the evaluation of the reliability of research. To ensure reliability, it is recommendable that two (or more) individuals will do the coding independently. The degree of agreement between coders is a 
measure of reliability in coding (Ghauri \& Grønhaug, 2002). Content analysis was by coding the innovativeness, creativity, and knowledge sharing factors and leadership behavior needs separately from each interview. The feedback from the interviews was given collectively. The feedback was shared so that the most common problems were stressed and no individual respondent could be identified.

The research material for this case was gathered between May and June 2007. 14 interviews were recorded, varying from one to one and a half hours. Our research subjects were white-collar workers, that is, 12 salespeople and the two owners of the company (referred to hereafter as the 'new leaders'). In addition, some of the salespeople had subordinates for whom they were responsible. Furthermore, pairs of salespeople were responsible for certain foreign customers. At the end of the year 2008, a follow-up meeting was held with all the company participants and their feedback and experiences were shared orally. Additionally, some participants also sent written feedback via email to the researchers who had given some written questions to consider at the end of the follow-up meeting.

Observational evidence is often useful in providing additional information about the topic being studied (Yin, 2003). The idea generation sessions of the Innovation Catcher were observed. The sessions were based on four themes: shared vision, ways to acquire customer-related knowledge, motivation, and practices for sharing the knowledge. In these sessions, ideation was done collectively with the help of creative methods. Four researchers facilitated the sessions and at the same time took notes about the session, especially the behavior of the leaders. The observation concentrated on the role of the leaders during the sessions: Did they participate in the sessions? Did they take part in conversations and group work? Did they generate ideas and insights? How did they behave and discuss during the session? How did employees seem to react on leaders' contributions or comments?

\section{Findings}

Next, the findings of this study are introduced. The quotations from the interviews are divided into different tables related to themes, such as interaction, knowledge sharing, leadership, etc. Answers from the interviews are bridged to the theory of transformational leadership and its four different dimensions, i.e., characteristics (detailed in Table 1, p. 26). Please note that all quotations are translated freely from native language to English by the authors.

\section{Challenges in Fuzzy Front-end Innovation Processes}

The problem pertaining to creativity and knowledge sharing in the case company has been that employees in different area units do not meet because of geographic distance. Usually short distances facilitate face-to-face interactions and thus foster knowledge transfer and innovation. Especially the transfer of tacit forms of knowledge is easier when the distance is small (Boschma, 2005; Knoben \& Oerlemans, 2006.) The geographic distance in the case company also means social distance between employees. The capacity of an organization to innovate may thus require social proximity (Boschma, 2005; Parjanen, 2012b). Even when the company atmosphere was described as good in the interviews, there was mistrust between employees in different area units. There were doubts as to whether employees in some other sales units work for their own interest or that of the whole company. The interviewees also revealed a different kind of working culture in area units. When organizational cultures or subcultures are similar, organizations are expected to interact more easily and with better results, because common interpretations and routines allow them to interpret and give meaning to actions without making all these interpretations explicit (Knoben \& Oerlemans, 2006). The challenge in innovation activities is to prompt members of different subcultures to interact with each other. 
Table 3. Quotations about interaction

\begin{tabular}{|c|c|c|}
\hline $\begin{array}{l}\text { Represen- } \\
\text { tative }\end{array}$ & Quotation & Characteristic \\
\hline $\begin{array}{l}\text { Sales Man- } \\
\text { ager }\end{array}$ & $\begin{array}{l}\text { We have had continuous changes and even the HQ has had } \\
\text { rapid developments. It is very normal that new salespeople are } \\
\text { not aware of all the details and procedures in all units. }\end{array}$ & $\begin{array}{l}\text { Inspirational } \\
\text { Motivation }\end{array}$ \\
\hline $\begin{array}{l}\text { Sales Man- } \\
\text { ager }\end{array}$ & $\begin{array}{l}\text { Before this merger, all salespeople handled their individual } \\
\text { market areas alone. Now they should handle things in pairs } \\
\text { with members from other units as well as from totally differ- } \\
\text { ent business cultures. }\end{array}$ & $\begin{array}{l}\text { Inspirational } \\
\text { Motivation }\end{array}$ \\
\hline $\begin{array}{l}\text { Vice Presi- } \\
\text { dent }\end{array}$ & $\begin{array}{l}\text { I think that it is not so easy to approach the owners of the } \\
\text { company and suggest any improvements. }\end{array}$ & $\begin{array}{l}\text { Inspirational } \\
\text { Motivation }\end{array}$ \\
\hline $\begin{array}{l}\text { Sales Man- } \\
\text { ager }\end{array}$ & $\begin{array}{l}\text { I am very familiar with everything and I know our own people } \\
\text { very well. They are sincere and therefore I am able to tell them } \\
\text { positive as well as negative things straight up. }\end{array}$ & $\begin{array}{c}\text { Individual } \\
\text { Consideration }\end{array}$ \\
\hline $\begin{array}{l}\text { Vice Presi- } \\
\text { dent }\end{array}$ & $\begin{array}{l}\text { Well, there are people who are not so willing to share informa- } \\
\text { tion and are quite happy to work as independently as possible. } \\
\text { They are very proud of their customer relations and do not } \\
\text { want anyone to interfere in those relations. }\end{array}$ & $\begin{array}{c}\text { Individual } \\
\text { Consideration }\end{array}$ \\
\hline $\begin{array}{l}\text { Sales Man- } \\
\text { ager }\end{array}$ & $\begin{array}{l}\text { It's not so easy to approach salespeople from different area } \\
\text { units. Such situations are stiffer than having this discussion } \\
\text { here; meaning that they are not big on small talk. }\end{array}$ & $\begin{array}{l}\text { Inspirational } \\
\text { Motivation }\end{array}$ \\
\hline $\begin{array}{l}\text { Sales Man- } \\
\text { ager }\end{array}$ & $\begin{array}{l}\text { Of course, there will always be this relationship between the } \\
\text { HQ and the area units. You cannot thoroughly unite people } \\
\text { unless you really put them concretely in the same office where } \\
\text { they have to meet every day. }\end{array}$ & $\begin{array}{l}\text { Inspirational } \\
\text { Motivation }\end{array}$ \\
\hline $\begin{array}{l}\text { Sales Man- } \\
\text { ager }\end{array}$ & $\begin{array}{l}\text { We do not really have collaboration on a daily basis with } \\
\text { salespeople at the HQ; especially as we all have our own areas } \\
\text { of responsibilities and, depending on the products, we might } \\
\text { be at different points of the market stages too. }\end{array}$ & $\begin{array}{l}\text { Idealized Influ- } \\
\text { ence }\end{array}$ \\
\hline
\end{tabular}

Most innovation happens at the boundaries between disciplines or specializations (Leonard, 1995). In the case company, ideas and knowledge have not crossed the borders of segments or departments, and one interviewee, for example, said that sales do not provide enough ideas to develop manufacturing. Carlile $(2002,2004)$ has shown how the creation of new knowledge is facilitated when knowledge boundaries are crossed. Working across boundaries is a key ingredient in competitive advantage and also explains why innovation is difficult to create and maintain. The level of novelty will determine the complexity of the knowledge boundary. When the level of novelty increases, the associated path-dependent nature of knowledge may have negative effects, and make knowledge sharing and creation difficult (Carlile, 2002, 2004).

The data revealed a need to develop a more open atmosphere. The leaders have tried to break this homogenous form by planning, together with the employees, different ways of sharing knowledge between individuals, as well as between area units, whilst emphasizing the importance of information from outside the organization (see Table 4). How organizations use the ideas and knowledge of external actors in their innovation processes is at the center of the open innovation model, 
and other similar conceptualizations of innovation (Laursen \& Salter, 2006). What open innovation means is that an organization needs to open up its boundaries to let valuable knowledge flow in from the outside in order to create opportunities for co-operative innovation processes with partners, customers and/or suppliers (Enkel, Gassmann, \& Chesbrough, 2009). The leaders of the case company highly valued the ability to absorb and share information from the customers. Many previous studies emphasize, among other knowledge sources, the importance of customers as a source of novel ideas. Everyone (even the weak links) is essential in sustaining the competitive advantage of the company. Therefore, it is crucial that knowledge and the developed systems are shared throughout the company.

Table 4. Quotations about knowledge sharing

\begin{tabular}{|c|c|c|}
\hline Representative & Quotation & Characteristic \\
\hline Sales Manager & $\begin{array}{l}\text { As the Vice President stated now there are about twen- } \\
\text { ty of us here today, it would be beneficial to share in- } \\
\text { formation amongst each other; particularly information } \\
\text { from those that actually visit customers and other area } \\
\text { units and are able to see and hear things. }\end{array}$ & $\begin{array}{l}\text { Idealized Influ- } \\
\text { ence }\end{array}$ \\
\hline Sales Manager & $\begin{array}{l}\text { The case is that when you go to meet people, you see } \\
\text { and hear things. Whilst there you might have ideas to } \\
\text { improve or develop things. }\end{array}$ & $\begin{array}{l}\text { Idealized Influ- } \\
\text { ence }\end{array}$ \\
\hline Sales Manager & $\begin{array}{l}\text { After this latest merger our procedures have changed a } \\
\text { lot. Perhaps this has also created the feeling that we are } \\
\text { allowed to develop things - people are more willing to } \\
\text { share ideas. }\end{array}$ & $\begin{array}{l}\text { Intellectual } \\
\text { Stimulation }\end{array}$ \\
\hline Vice President & $\begin{array}{l}\text { Of course, salespeople pass information to me, but I } \\
\text { like to make calls and have personal conversations with } \\
\text { them because they are the ones who see and hear things } \\
\text { on the spot. }\end{array}$ & $\begin{array}{l}\text { Intellectual } \\
\text { Stimulation }\end{array}$ \\
\hline Vice President & $\begin{array}{l}\text { Trying to challenge Sales Managers to be more active } \\
\text { with customer relations. }\end{array}$ & $\begin{array}{l}\text { Intellectual } \\
\text { Stimulation }\end{array}$ \\
\hline Sales Manager & $\begin{array}{l}\text { There is definitely nothing negative about it. No one } \\
\text { has said "Do not think. Do not develop." But I have } \\
\text { had the feeling a few times that ideas are not taken on } \\
\text { board - even to the point of considering investigating } \\
\text { the matter. }\end{array}$ & $\begin{array}{l}\text { Intellectual } \\
\text { Stimulation }\end{array}$ \\
\hline
\end{tabular}

\section{Leadership and the Required Conditions for the Action Research Process}

The case company had recently experienced a change in leadership. The case company leadership is quite traditional but the atmosphere is gradually changing. One example is that the new leaders decided to take part in the Innovation Catcher project. The new leaders are still dealing with the baggage that the former leader created over the years. The former leader still influences day-today affairs in the organization. As was stated several times in the interviews, the former leader was very demanding and challenging but he also made the company successful for many years. The employees' perceptions of the former leader are respectful and grateful. One respondent said: 
"As annoying and frustrating as it may be that the former leader might, for example, have sold products to another customer that you had already promised to another, you cannot really be mad at him because you notice yourself admiring him because, even in his old age, he had a special hunch as to how to keep the business going successfully".

Naturally, some respondents felt that changes at the ownership level were more than welcome. Some interviewees mentioned that one advantage regarding their own job development is that it is easier to discuss their future plans with the new leaders of the same age group. The perceptions of the leadership in the case company are introduced in the next Table.

Table 5. Quotations about leadership

\begin{tabular}{|l|l|c|}
\hline Representative & Quotation & Characteristic \\
\hline Sales Manager & $\begin{array}{l}\text { With the new leaders it is easier to bring out your own } \\
\text { ideas than with the former leader. There was a huge } \\
\text { gap with him; he'd been leading in his own style for so } \\
\text { long and it was not so easy to just make small talk with } \\
\text { him. }\end{array}$ & $\begin{array}{c}\text { Idealized Influ- } \\
\text { ence }\end{array}$ \\
\hline Vice President & $\begin{array}{l}\text { It is quite nice to think over these things. We must be } \\
\text { developing. I'm not so interested in the situations } \\
\text { where we would have to reach for external help, mean- } \\
\text { ing consulting. It would mean, in my view, that in such } \\
\text { a case I would have failed. I think that the company } \\
\text { should be able to figure things out on its own as much } \\
\text { as possible. So this is a very good way to develop } \\
\text { things - with the university. }\end{array}$ & $\begin{array}{c}\text { Idealized Influ- } \\
\text { ence }\end{array}$ \\
\hline Sales Manager & $\begin{array}{l}\text { This kind of development project should have been } \\
\text { organized a bit earlier - specifically, when our last } \\
\text { merger with our newest area unit was taking place. But } \\
\text { better late than never. }\end{array}$ & $\begin{array}{c}\text { Idealized Influ- } \\
\text { ence }\end{array}$ \\
\hline Sales Manager & $\begin{array}{l}\text { Compared to the former leader, the new leaders are } \\
\text { more approachable, energetic, and they both have com- } \\
\text { passionate personalities. }\end{array}$ & $\begin{array}{c}\text { Idealized Influ- } \\
\text { ence }\end{array}$ \\
\hline Sales Manager & $\begin{array}{l}\text { In my opinion, having you here from the university } \\
\text { brings all the salespeople together, aiming to develop } \\
\text { our practices and products so that we could be more } \\
\text { independent abroad. Currently, we are leaning quite a } \\
\text { lot on our leaders. }\end{array}$ & $\begin{array}{l}\text { Inspirational } \\
\text { Motivation }\end{array}$ \\
$\begin{array}{l}\text { This project seems to be a platform that enables devel- } \\
\text { oping collaboration, idea generation, and deepening } \\
\text { informal conversations. I mean that, in this case, this is } \\
\text { a really good thing. }\end{array}$ & $\begin{array}{c}\text { Inspirational } \\
\text { Motivation }\end{array}$ \\
\hline
\end{tabular}

Both the new leaders and the employees are obviously interested in sustaining the competitive business environment and some changes can clearly be seen. First of all, there are two new leaders with noticeably different formal roles (see Table 6). The Vice President is focused on people and innovation processes, and he operates mainly from the headquarters. The President is more 
responsible for finance and systems, and he moves between the company units and the headquarters. Thus, both leaders can influence different kinds of people and appeal to various emotional levels (Bass \& Riggio, 2006). However, the main point is not related leaders' formal roles in the organization, instead it is more beneficial for the company when all participants get along, share thoughts and ideas, and are committed to developing the work environment and processes collectively (Paalanen \& Hyypiä, 2008).

\section{Table 6. Quotations about leadership roles}

\begin{tabular}{|l|l|c|}
\hline Representative & Quotation & Characteristic \\
\hline Vice President & $\begin{array}{l}\text { I make visits to different teams and units, trying to mo- } \\
\text { tivate them and developing team spirit. However, it is } \\
\text { not always positive matters that I have to handle, some- } \\
\text { times there are really unpleasant things to discuss. }\end{array}$ & $\begin{array}{c}\text { Idealized Influ- } \\
\text { ence }\end{array}$ \\
\hline President & $\begin{array}{l}\text { The Vice President and I have divided our tasks and } \\
\text { responsibilities My responsibilities are certain business } \\
\text { branches, certain area units, and I'm more responsible } \\
\text { for financial matters. }\end{array}$ & $\begin{array}{c}\text { Idealized Influ- } \\
\text { ence }\end{array}$ \\
\hline Vice President & $\begin{array}{l}\text { My motivation does not come from financial figures, } \\
\text { even though they are very important to the company. } \\
\text { My motivation is about making things run smoothly, } \\
\text { ensuring people feel good, achieve targets and succeed } \\
\text { in their activities. }\end{array}$ & $\begin{array}{c}\text { Inspirational } \\
\text { Motivation }\end{array}$ \\
\hline President & $\begin{array}{l}\text { I think one of our tasks is to create possibilities to test } \\
\text { ideas and to accept some failures too. }\end{array}$ & $\begin{array}{c}\text { Intellectual } \\
\text { Stimulation }\end{array}$ \\
\hline Sales Manager & $\begin{array}{l}\text { Both new leaders are good at listening and they do not } \\
\text { forbid anything immediately. It is a very good leader- } \\
\text { ship characteristic - patience. }\end{array}$ & $\begin{array}{c}\text { Individual Con- } \\
\text { sideration }\end{array}$ \\
\hline Sales Manager & $\begin{array}{l}\text { With the new leaders I achieve decisions rapidly, which } \\
\text { is beneficial of my duties. }\end{array}$ & $\begin{array}{c}\text { Individual Con- } \\
\text { sideration }\end{array}$ \\
\hline Sales Manager & $\begin{array}{l}\text { I have had a straight answer from the leader that 'this is } \\
\text { a good thing, 'go for it' or 'this not quite right', 'let's } \\
\text { skip it for now'. }\end{array}$ & $\begin{array}{c}\text { Individual Con- } \\
\text { sideration }\end{array}$ \\
\hline
\end{tabular}

Different characteristics were not interpreted as actions from a certain leader (the Vice President or the President) during the development process. Instead, it became obvious that TL characteristics can be shared and successfully performed simultaneously by the two leaders during the same development process with the same participants. In this study, shared leadership roles among individuals enabled creativity and a collaborative atmosphere. Comparing the era and leadership behavior with that of the former leader, the new leaders were more effective in encouraging their employees to try completely new, or even uncertain, conditions in their daily practices. Additionally, by sharing the TL style, the leaders were more often able to give the valuable individual attention and support to the sales managers (Bass \& Riggio, 2006).

\section{Supporting Creativity by Leadership}

The aim of TL behavior is to be involved with the participants in fuzzy-front end innovation processes rather than be the source of groups' innovation (Bass \& Riggio, 2006; Birasnav et al., 
2011). In the case company, the leaders have contributed, for example, to the meetings where it was considered how and why knowledge should be shared. By appearing as role models, the leaders have challenged the participants to do the same, and perhaps even more, in the meetings aimed at developing creativity and communication in the organization. In addition, rapid changes in the industry in general accentuate the need for diversified knowledge as well as creativity in the organization.

All the interviewed research participants were very busy, important individuals. The effort they made to attend the required meetings was essential. Their busy schedules rarely allow for a meeting to simply develop their own tasks and working environment. One major point in the case company has been the participation of the leaders (see Table 7). They have both been present at all the meetings and tried to contribute as one of the "regular workers". All the employees in these meetings have also gained, at least to some extent, the attention of the leaders and have had extra support to their ideas and demands, as TL theory suggests. Many interviewees said that, compared to the former leader, it is easier to discuss things with these leaders. They have contributed, for example, to the tasks that this research has challenged the participants to do. In this way, they have been able to stimulate employees to create new ideas and encourage them to improve the current functions (Bass \& Riggio, 2006; Birasnav et al., 2011). It is crucial to establish a trustworthy atmosphere, which helps employees to overcome their reluctance to share knowledge (Miles et al., 2005).

\section{Table 7. Quotations about participation}

\begin{tabular}{|l|l|c|}
\hline Representative & Quotation & Characteristic \\
\hline Sales Manager & $\begin{array}{l}\text { This is a very good company; meaning that these own- } \\
\text { ers have a really strong vision and, undeniably, have } \\
\text { succeeded so well that, of course, it is hard for anyone } \\
\text { to go and say that there might be things that they (the } \\
\text { owners) do wrong. But somehow I think that people are } \\
\text { not so committed to their work or organization, and I } \\
\text { believe there is plenty of room for improvements. It } \\
\text { would also be a competitive advantage if people would } \\
\text { put more effort toward their tasks and information shar- } \\
\text { ing. }\end{array}$ & $\begin{array}{c}\text { Idealized Influ- } \\
\text { ence }\end{array}$ \\
\hline Sales Manager & $\begin{array}{l}\text { It's really our asset to be able to be rapid and flexible in } \\
\text { different situations. In the markets we are much faster } \\
\text { than our bigger competitors. In this circumstance, we } \\
\text { should be able to make more out of it - in order to sus- } \\
\text { tain this advantage in the future - maybe even do bet- } \\
\text { ter. }\end{array}$ & $\begin{array}{c}\text { Idealized Influ- } \\
\text { ence }\end{array}$ \\
\hline Sales Manager & $\begin{array}{l}\text { We had this person who had a lot of ideas. He was also } \\
\text { very brave, because sometimes the ideas were good and } \\
\text { sometimes they weren't that good. But his behavior } \\
\text { could be quite challenging to the company and produc- } \\
\text { tion level. It is good though, that even mistakes are ac- } \\
\text { cepted. }\end{array}$ & $\begin{array}{c}\text { Intellectual } \\
\text { Stimulation }\end{array}$ \\
\hline
\end{tabular}




\begin{tabular}{|l|l|c|}
\hline Sales Manager & $\begin{array}{l}\text { In my opinion there should be more and more meetings } \\
\text { where we focus on development and innovative solu- } \\
\text { tions. I think this is also a necessity if we wish to sus- } \\
\text { tain competitive advantage and make a difference } \\
\text { among competitors. }\end{array}$ & $\begin{array}{c}\text { Intellectual } \\
\text { Stimulation }\end{array}$ \\
\hline Sales Manager & $\begin{array}{l}\text { It is rewarding for me to have a job that is independent } \\
\text { and I have a room for my own thoughts and solutions. } \\
\text { Readymade and strict instructions are not for me. }\end{array}$ & $\begin{array}{c}\text { Intellectual } \\
\text { Stimulation }\end{array}$ \\
\hline Sales Manager & $\begin{array}{l}\text { This is a really good place to work: you are able to self- } \\
\text { actualize, you have responsibilities and the power to } \\
\text { make a difference. Of course, this demands good self- } \\
\text { esteem and the capability to perform at your best. }\end{array}$ & $\begin{array}{c}\text { Intellectual } \\
\text { Stimulation }\end{array}$ \\
\hline Sales Manager & $\begin{array}{l}\text { Well, now we are having some feedback in our meet- } \\
\text { ings, we are simplifying area tasks and responsibilities, } \\
\text { and even have individual budget targets. }\end{array}$ & $\begin{array}{c}\text { Individual Con- } \\
\text { sideration }\end{array}$ \\
\hline Sales Manager & $\begin{array}{l}\text { I appreciate that we are allowed to work independently } \\
\text { and we are not demanded to check every little thing } \\
\text { from top management. And this allows us to be quite } \\
\text { free to develop and try different things. }\end{array}$ & $\begin{array}{c}\text { Individual Con- } \\
\text { sideration }\end{array}$ \\
\hline
\end{tabular}

Based on the interviews, a baseline for enhancing creativity is a clear and shared vision for the future. Additionally, the leadership style should be proactive as well as allowing mistakes to be made. Regular meetings and interaction were seen highly valuable for boosting collaboration. It was also greatly appreciated by the sales managers that the leaders wanted to raise the level of development and innovations in the existing systems - and not bring completely new requirements into the already busy daily practices. The sales managers considered that freedom, responsibility, power, and autonomy cultivate willingness to develop and share ideas. Pride in being an employee of this organization and trust gained from the leaders were points also construed in the interviews. Furthermore, the sales managers feel that they are allowed to be and to perform as they are, in other words - they feel that they are accepted as themselves.

\section{Discussions and Implications}

In order to enhance creativity and motivation in fuzzy front-end innovation processes, the research participants decided to organize meetings at the different units of the company. At very meeting present were the salespeople and people from the operational level intent on gaining information from different units and levels of the organization. The meetings, even though casual in nature, had a certain agenda and aimed at achieving a better understanding of each other's work and better transferability of knowledge throughout the company. There was also an interest to use different creativity methods to solve problems.

The salespeople were enthusiastic in developing the systems and knowledge sharing. Their relatively independent work required the support of the whole organization. The leaders' behavior related to idealized influence and individual consideration had had a positive effect on the employees' motivation, commitment, and trust. To achieve this or get any extra effort from the employees for the organization, open communication and the leaders' own commitment had to be made visible. Naturally, the character of the employee significantly influences the leadership behavior, because the employees must also be open-minded and ready to try something new in order to develop knowledge sharing and creativity in the innovation processes in the organization. 
According to the follow-up research and the meeting at the company, the development project was essential. However, the situation was very different at the end of the project compared to the beginning of it. At the beginning, the volume of customers was such that they had, and were willing, to wait for their orders from the company, which could easily deliver the required products and services. Everyone was quite satisfied and sales were running smoothly. At the end of the project the whole wood processing industry experienced significant changes and the impact was global. Customers' needs could no longer be met and even the basic bulk products, previously the main sales area, were lacking. However, the company did not stand still but eagerly innovated more advanced products and service concepts.

During the development process it became necessary to change the primary goal of the Innovation Catcher. The original idea was to share knowledge and ideas among colleagues, i.e. an attempt to organize individuals' intellectual capital and silent information. The changes in the global wood industry, however, forced the company to seek more concrete ideas to further develop wood products and services for customers. This was also explained by the company president who stated in the meeting: "Since we have now adapted to the changes required by the global wood industry, it is time to look back and remember the main reason why this particular development process was adopted by our organization".

In the feedback, one respondent stated: "Perhaps we need more help from people outside the company, in order to continue the good development work that we started with the Innovation Catcher". In other words, none of the respondents was dissatisfied with the Innovation Catcher, and even though the main idea of the project had to change, the process was able to meet the required changes in general. Some changes were suggested in order to improve the Innovation Catcher, such as meeting practices being more optional to the participants and more informal conversations. In addition, there was a proposal about smaller team meetings to avoid having too many people attending each meeting. Having clearer targets for all new projects from the very beginning was also considered to be an advantage.

The aim of this study is to answer how creativity in fuzzy front-end innovation processes can be supported by transformational leadership. TL behavior can be applied to creativity and innovation processes, especially if related to actions when leadership is seen as different roles during a process, instead of as actions or characteristics of a certain individual role. The leaders and managers of the case study were able to successfully set aside their formal tasks and responsibilities at an individual level and use their leadership for transformation, gaining successful and innovative collaboration throughout the organization. The perception of leadership and commitment as well as the development level of employees are critical aspects to consider because leadership behavior only has a limited ability to control knowledge; it can only organize enabling conditions and opportunities to push employees (Miles et al., 2000). Thus, with TL, creation and generation of ideas are more likely to occur. Appropriate leadership behavior needs to be tailored to fit complex and diversified organization settings and still retain the encouraging atmosphere required for knowledge creation (Bass \& Riggio, 2006; Yukl, 1998). TL ensures that the company reaches the next level; the obtained knowledge will become organizational wisdom (Bass \& Avolio, 2000). In this situation, an organization does not lose knowledge, even if it were to lose one of its employees or experts.

The study has some obvious limitations: the sample is part of a wider research project and its response was minor; therefore, any findings can be treated as exploratory and no generalizations can be made. Furthermore, the study was conducted in a family-owned organization and thus does not represent a 'conventional' business environment in the international wood processing industry in Finland. Therefore, the data merely describes the challenges to leadership and managerial roles within the creativity and innovation context of the organization. 


\section{Conclusion}

Innovations are widely seen as the driving force of economic growth and competitiveness. Creativity is an essential part of innovation. By enabling knowledge sharing opportunities and chances for collaboration in daily practices, leadership supports efforts towards creativity and innovation. Many TL studies are quantitative and literature review based (e.g., Birasnav et al. 2011; Gumusluoglu \& Ilsev, 2009; Joo et al., 2012; Liu \& DeFrank, 2011). This case study, which includes a qualitative example, increases the understanding of how TL affects an organization's ability to enhance its creativity and innovation in practice during the development processes.

According to Bass and Riggio (2006) the different characteristics of TL are all needed in order to influence people. And as a consequence, this data does not let us suggest directly which characteristics of TL would be more essential than others in enhancing the creativity in fuzzy front-end innovation processes. However, at the beginning of the development process it was construed that the participants emphasized idealized influence and inspirational motivation in dominant leadership styles. Individual consideration characteristic was also valued highly by sales managers but this characteristic was perceived at certain phases of the development process. Though, this characteristic was interpreted as a premised style for independent working methods of sales managers and the individual consideration should be offered by leaders at all times. At the end of the development work, and when dealing with issues like knowledge sharing, an emphasis on intellectual stimulation in leadership style clearly rose from the data.

A novelty in the managerial implications based on this case study is that despite the formal and "traditional" roles of leadership (Kotter, 1990; Miles \& Snow, 1986; Mintzberg, 1989; Ulrich \& Beatty, 2002), the new leaders were able to use the characteristics of TL successfully and simultaneously in the same development process without any agreement in advance. These results give the authors reason to suggest that leadership is highly beneficial when shared among diverse individuals without too strict differentiations (Drucker, 2007; Sydänmaanlakka, 2003). Together the new leaders were able to influence all sales managers and have better engagement and communication about creativity, knowledge sharing and innovation.

Innovation is often dependent upon dissimilar knowledge and skills, which makes diversity important. This means that organizations need to be able to capitalize on diversity of their employees. Creative ideas and innovation potential is likely to be found in the diversity of knowledge, skills, and experience. Future studies should concentrate more on the benefits of diversity between employees and somehow examine what degree or kind of diversity is most beneficial. Additionally, it could be fruitful to explore TL and its characteristics beyond the organizational job descriptions, for example, and study the required leadership roles based on their context at different phases of organization development processes.

\section{References}

Adamides, E., \& Karacapilidis, N. (2004). Information technology support for the knowledge and social processes of innovation management. Technovation, 26, 50-59.

Alam, I. (2006). Removing the fuzziness from the fuzzy front-end of service innovations through customer interactions. Industrial Marketing Management, 35, 468-480.

Amabile, T. M. (1996). Creativity in context. Boulder, CO: Westview Press.

Amabile, T. M. (1997). Motivating creativity in organizations: On doing what you love and loving what you do. California Management Review, 40(1), 39-58.

Amabile, T. M. (1998). How to kill creativity. Harvard Business Review, 76(5), 76-87.

Amabile, T. M., Conti, R., Coon, H., Lazenby, J., \& Herron, M. (1996). Assessing the work environment for creativity. Academy of Management Journal, 39(5), 1154-1184. 
Axtell, C., Holman, D., Unsworth, K., Will, T., Waterson, P., \& Harrington, E. (2000). Shopfloor innovation: Facilitating the suggestion and implementation of ideas. Journal of Occupational and Organizational Psychology, 39, 599-617.

Bass, B. M. (1985). Leadership and performance beyond expectations. New York: Free Press.

Bass, B. M., \& Avolio, B. (2000). MLQ: Multifactor leadership questionnaire (2nd ed.), Redwood City, CA: Mind Garden.

Bass, B. M., \& Riggio, R. E. (2006). Transformational leadership (2nd ed.). New Jersey, USA: Lawrence Erlbaum Associates.

Birasnav, M., Rangnekar, S., \& Dalpati, A. (2011). Transformational leadership and human capital benefits: The role of knowledge management. Leadership \& Organization Development Journal, 32(2), $106-126$.

Bogers, M., \& West, J. (2010). Contrasting innovation creation and commercialization within open, user and cumulative innovation. Working paper. San José State University, San José, CA.

Boschma, R. (2005). Proximity and innovation: A critical assessment. Regional Studies, 39(1), 61-74.

Burns, J. M. (1978). Leadership. New York: Harper \& Row.

Carlile, R. P. (2002). A pragmatic view of knowledge and boundaries: Boundary objects in new product development. Organization Science, 13, 442-455.

Carlile, R. P. (2004). Transferring, translating, and transforming: An integrative framework for managing knowledge across boundaries. Organization Science, 15, 555-568.

Chesbrough, H. (2003). Open innovation. The new imperative for creating and profiting from technology. Boston: Harvard Business School Press.

Christensen, J. F., Olesen, M. H. \& Kjaer, J. S. (2005). The industrial dynamics of open innovation - Evidence from the transformation of consumer electronics. Research Policy, 34(10), 1533-1549.

de Jong, J. P. J., \& Kemp, R. (2003). Determinants of co-workers' innovative behaviour: An investigation into knowledge intensive services. International Journal of Innovation Management, 7(2), 189-212.

Drazin, R., Glynn, M. A., \& Kazanjian, R. K. (1999). Multilevel theorizing about creativity in organizations: a sensemaking perspective. Academy of Management Review, 24(2), 286-307.

Drucker, P. F. (1964). Managing for results. New York: Harper \& Row.

Drucker, P. F. (2007). Management tasks, responsibilities, practices. New Brunswick, USA: Transaction Publishers.

Enkel, E., Gassmann, O., \& Chesbrough, H. (2009). Open R\&D and open innovation: Exploring the phenomenon. $R \& D$ Management, 39(4), 311-316.

Felberg, J. D., \& DeMarco, D. A. (1992). From experience: New idea enhancement at Amoco Chemical: An early report from a new system. Journal of Product Innovation Management, 9, 278-286.

Forssén, M. (2001). Life cycles of organizational 'bottom-up' development ideas. Knowledge and Process Management, 8(4), 249-261.

Ghauri, P., \& Grønhaug, K. (2002). Research methods in business studies: A practical guide (2nd ed.). Essex: Prentice Hall.

Gumusluoglu, L., \& Ilsev, A. (2009). Transformational leadership, creativity, and organizational innovation. Journal of Business Research, 62(4), 461-473.

Hirsijärvi, S., \& Hurme, H. (2000). Tutkimushaastattelu: Teemahaastattelun teoria ja käytäntö [Interview as a method for qualitative research: Theory and practice of the qualitative research interview]. Helsinki, Finland: University Press - Yliopistopaino.

Herstatt, C., \& Verworn, B. (2001). The "fuzzy front end" of innovation (Working Paper 4.). Hamburg: Hamburg University of Technology. 
Huusko, L. (2006). What is expected from supervisors? One more factor to explain the problems in teamwork. Team Performance Management, 12(3/4), 91-101.

Jacobsen, K., Hofman-Bang, P., \& Nordby, R., Jr. (2005). The IC rating model by Intellectual Capital Sweden. Journal of Intellectual Capital, 6(4), 570-587.

Johansson, F. (2004). The Medici effect: Breakthrough insights at the intersection of ideas, concepts and cultures. Boston: Harvard Business School Press.

Joo, B-K., Yoon, H. J., \& Jeung, C-W. (2012). The effects of core self-evaluations and transformational leadership on organizational commitment. Leadership \& Organization Development Journal, 33(6), 564-582.

Kallio, A., \& Bergenholtz, C. (2011). Generating innovation opportunities - Exploring and absorbing customer knowledge. International Journal of Technology Management, 56, 172-187.

Kallio, A., \& Konsti-Laakso, S. (2011, September). An employee-driven organisational innovation system Experiences from Innovation Catcher. Paper presented at the 11th International Conference of The Continuous Innovation Network (CINet) Aarhus, Denmark.

Kesting, P., \& Ulhøi, J. (2010). Employee-driven innovation: Extending the license to foster innovation. Management Decision, 48(1), 65-84.

Khurana, A., \& Rosenthal, S. R. (1998). Towards holistic "front ends" in new product development. The Journal of Product Innovation Management, 15(1), 57-74.

Knight, R. M. (1987). Corporate innovation and entrepreneurship: A Canadian study. Journal of Product Innovation Management, 4, 284-297.

Knoben, J., \& Oerlemans, L. A. G. (2006). Proximity and inter-organizational collaboration: A literature review. International Journal of Management Reviews, 8(2), 71-89.

Koen, P., Ajamian, G., Boyce, S., Clamen, A., Fisher, E., Fountoulakis, S., Johnson, A., Puri, P., \& Seibert, R. (2002). Fuzzy front end: Effective methods, tools, and techniques. In P. Belliveau, A. Griffin, \& S. Somermeyer (Eds.), The PDMA ToolBook for new product development (pp. 2-35). New York: John Wiley \& Sons.

Kotter, J. P. (1990). A force for change: How leadership differs from management. New York: Free Press.

Kotter, J. P. (1996). Leading change. Boston: Harvard Business School Press.

Kotter, J. P., \& Cohen, D. (2002). Creative ways to empower action to change the organizations: Cases in Point. Journal of Organizational Excellence, 22(1), 73-82.

Laursen, K., \& Salter, A. (2006). Open for innovation: The role of openness in explaining innovation performance among U.K. manufacturing firms. Strategic Management Journal, 27, 131-150.

Leonard, D. (1995). Wellsprings of knowledge. Building and sustaining the sources of innovation. Boston: Harvard Business School Press.

Lettl, C., Herstatt, C., \& Gemuenden, H.G. (2006). User's contributions to radical innovation: Evidence from four cases in the field of medical equipment technology. $R \& D$ Management, 36(3), 251-272.

Liu, Y., \& DeFrank, R. S. (2011, August). Self-interest and knowledge sharing intentions: The impacts of leadership climate and HR practices. Paper presented at the $71^{\text {st }}$ Annual Meeting of the Academy of Management Conference, San Antonia, Texas, USA.

Lunenburg, F. C. (2011). Leadership versus management: A key distinction - at least in theory. International Journal of Management, Business, and Administration, 14(1), 1-4.

Madjar, N. (2005). The contributions of different groups of individuals to employees' creativity. Advances in Developing Human Resources, 7(2), 182-206.

McDonald, D., \& Makin, P. (2000). The psychological contract, organisational commitment and job satisfaction of temporary staff. Leadership \& Organization Development Journal, 21(2), 84-91.

Miles, R. E., Miles, G., \& Snow, C. C. (2000). The Future.Org. Long Range Planning, 33, 300-321. 
Miles, R. E., Miles, G. \& Snow, C. C. (2005). Collaborative entrepreneurship. California: Stanford business books.

Miles, R. E., \& Snow, C. C. (1986). Network organizations: New concepts for new forms. California Management Review, 28, 62-73.

Milliken, F. J., \& Martins, L. L. (1996). Searching for common threads: Understanding the multiple effects of diversity in organizational groups. The Academy of Management Review, 21(2), 402-433.

Mintzberg, H. (1989). Inside our strange world of organizations. New York: Free Press.

Mumford, M., \& Gustafson, S. (1988). Creativity syndrome: Integration, application, and innovation. Psychological Bulletin, 103, 27-43.

Mumford, M., Scott, G., Gaddis, B., \& Strange, J. (2002). Leading creative people: Orchestrating expertise and relationships. The Leadership Quarterly, 13, 705-750.

Nahapiet, J., \& Ghostal, S. (1998). Social capital, intellectual capital and the organizational advantage. Academy of Management Review, 23(2), 242-266.

Nayak, A. (2008). Experiencing creativity in organisations: A practice approach. Long Range Planning, 41, $420-439$.

Nijhof, A., Krabbendam, K., \& Looise, J.C. (2002). Innovation through exemptions: Building upon the existing creativity of employees. Technovation, 22(11), 675-683.

Nonaka, I., \& Takeuchi, H. (1995). The knowledge-creating company. New York: Oxford University Press.

Oikarinen, T. (2008). Organisatorinen Oppiminen - tapaustutkimus oppimisprosessien jännitteistä teollisuusyrityksessä [Organizational learning - Case-study of tensions in learning processes in industrial enterprises]. Acta Universitatis Lappeenrantaensis 299, Diss. Lappeenranta University of Technology, Finland.

Oldham, G., \& Cummings, A. (1996). Employee creativity: Personal and contextual factors at work. Academy of Management Journal, 39, 607-634.

Paalanen, A., \& Hyypiä, M. (2008, March). Enhancing employees' innovation activity through motivational factors. Paper presented at the Conference on Regional Development and Innovation Processes, Porvoo - Borga, Finland.

Parjanen, S. (2012a). Creating possibilities for collective creativity, brokerage functions in practice-based innovation. Acta Universitatis Lappeenrantaensis 474, Diss. Lappeenranta University of Technology, Finland.

Parjanen, S. (2012b). Innovation sessions as sources of new ideas. International Journal of Innovation and Learning, 11(4), 352-368.

Parjanen, S. (2012c). Experiencing creativity in the organization: From individual creativity to collective creativity. Interdisciplinary Journal of Information, Knowledge, and Management, 7, 109-128. Retrieved from http://www.ijikm.org/Volume7/IJIKMv7p109-128Parjanen586.pdf

Parzefall, M.-R., Seeck, H., \& Leppänen, A. (2008). Employee innovativeness in organizations: A review on the antecedents. Finnish Journal of Business Economics, 2, 165-182.

Paulus, P. (2000). Groups, teams and creativity: The creative potential of idea generating groups. Applied Psychology: An International Review, 49, 237-262.

Pöyhönen, A. (2006, September). Development and validation of a survey instrument for measuring organizational renewal capability. Paper presented at the 7 th international conference of Continuous Innovation Network (CINet), Lucca, Italy.

Schein, E. (1999). Empowerment, coercive persuasion and organizational learning: Do they connect? The Learning Organization, 6(4), 163-172.

Senge, P. M. (2003). Taking personal change seriously: The impact of organizational learning on management practice. Academy of Management Executive, 17(2), 47-50. 
Sydänmaanlakka, P. (2003). Intelligent leadership and leadership competencies, Developing a leadership framework for intelligent organizations. Doctoral Dissertation, University of Technology, Helsinki.

Thomas, K. W., \& Velthouse, B. A. (1990). Cognitive elements of empowerment: An interpretive model of intrinsic task motivation. Academy of Management Review, 15, 666-681.

Tsui, A. S., \& Wu, J. B. (2005). The new employment relationship versus the mutual investment approach: implications for human resource management. Human Resource Management, 22(2), 115-121.

Ulrich, D., \& Beatty, R. (2002). The role of the HR professionals in the virtual organization. In R. L. Heneman \& D. B. Greenberger (Eds.), Human resource management in virtual organizations (pp. 103124). Charlotte, NC: Information Age Publishing.

Viitala, R. (2004), Esimiehet osaamisen johtajina. [Managers as leaders of know-how]. University of Vaasa, Finland.

Viitala R. (2005). Johda osaamista! Osaamisen johtaminen teoriasta käytäntöön [Lead know-how! From the theory of leading know-how into practice]. Helsinki: Infoviestintä Oy.

von Hippel, E. (1988). The sources of innovation. New York: Oxford University Press.

Wan, D., Ong, C. H., \& Lee, F. (2005). Determinants of firm innovation in Singapore. Technovation, 25(3), 261-268.

Woodman, R., Sawyer, J., \& Griffin, R. (1993). Toward a theory of organizational creativity. The Academy of Management Review, 18(2), 293-321.

Yin, R. (2003). Applications for case study research (2nd ed.). California: Sage Publications.

Yukl, G. (1998). Leadership in organizations. Upper Saddle River, New Jersey: Prentice Hall.

\section{Biographies}

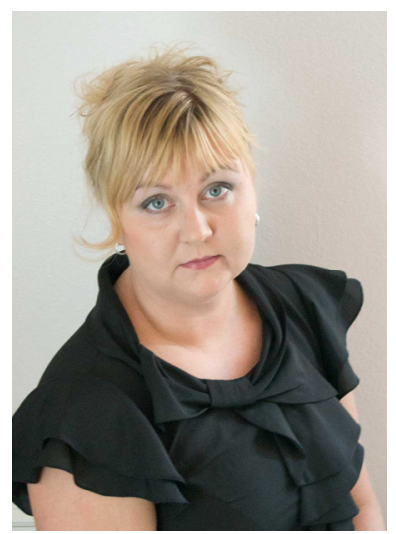

Mirva Hyypiä, M.Sc. (Econ.\&Bus.Adm.) is a Researcher at Lappeenranta University of Technology, Lahti School of Innovation, Finland. Her current research interests are leadership behaviour and management roles in the innovation processes and in the complex environments, which are also the topics of her post-graduate studies. She has published for example in Journal of Advances in Management Research and International Journal of Entrepreneurial Venturing.

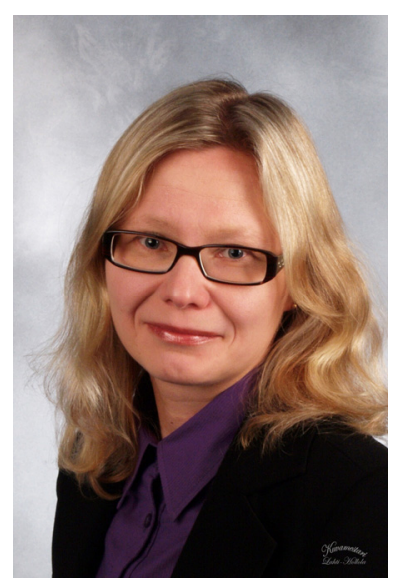

Satu Parjanen, D.Sc. (Tech.), is a Senior Researcher at Lappeenranta University of Technology, Lahti School of Innovation, Finland. Her research interests are related to collective creativity, brokerage functions, and distances as sources of innovation. She has published for example in European Journal of Innovation Management, International Journal of Innovation and Learning and European Planning Studies. 